\title{
MODALITETI POVREDE MEDICINSKOGA TRETMANA LIJEČNIKA S OSVRTOM NA TERAPIJSKU LIJEČNIČKU POGREŠKU U HRVATSKOJ I POREDBENOJ PRAKSI
}

\author{
Dr. sc. Hrvoje Vojković*
}

\author{
UDK 347.56:614.25(497.5) \\ https://doi.org/10.30925/zpfsr.42.3.10 \\ Ur.: 2. rujna 2021. \\ Pr.: 2. studenoga 2021. \\ Prethodno priopćenje
}

\begin{abstract}
Sažetak
Istraživanje pojavnih oblika štetnih radnji u sklopu medicinskog tretmana polazi od temeljne obveze liječnika da pri pružanju zdravstvene usluge primjenjuju općeprihvaćeni medicinski standard, kao i standard dužne pozornosti koji je prikladan liječničkoj struci. U radu se istražuju pravno relevantni modaliteti povrede medicinskoga standarda te se izlaže temeljna klasifikacija dijagnostičkih, terapijskih $i$ atipičnih liječničkih pogrě̌ki s naglaskom na pojavne oblike terapijske pogreške u medicinskoj i pravnoj praksi u Hrvatskoj te ad comparandum. U tom smislu bitno područje istraživanja čini prikupljena reprezentativna zbirka domaće $i$ strane prakse u zadnjih 25 godina. Zaključnim razmišljanjima zaokružuje se opća tipologija pravno relevantnih štetnih radnji kojima se ostvaruje povreda medicinskoga tretmana liječnika, u skladu s normama pozitivnoga prava te prihvaćenim stajalištima sudske prakse.
\end{abstract}

Ključne riječi: građanskopravna odgovornost liječnika; dužna pažnja liječnika; povreda standarda medicinskog tretmana; terapijska lijě̌nička pogrě̌ka.

\section{UVODNE NAPOMENE}

Pitanje modaliteta povrede medicinskoga tretmana, odnosno praktične tipologije štetnih radnji liječnika tema je koja ne gubi na aktualnosti napose u svjetlu recentnih podataka iz država članica Europske unije. Naime, podatci pokazuju da se neki oblik odstupanja u primjeni važećih medicinskih pravila pojavljuje prosječno u čak 10 \% svih dijagnostičko-terapijskih tretmana. ${ }^{1}$ To je praćeno porastom broja odštetnopravnih postupaka, ${ }^{2}$ kao i porastom prosječnoga izravnog i neizravnog troška

* Dr. sc. Hrvoje Vojković, Gras Savoye Croatia d.d. Zagreb, Willis Towers Watson Group; hvojkovic@gmail.com. ORCID: https://orcid.org/0000-0002-2531-2460.

1 Prema WHO Europe, pristup 4. listopada 2019., http://www.euro.who.int/en/health-topics/ Health-systems/patient-safety/data-and-statistics.

2 Umberto Tarantino et al., „Profesional Liability in Orthopaedics and Traumatology in Italy“, 
tako nastalih šteta, koje samo u Italiji dosežu iznos od čak 10 milijardi eura per anno. ${ }^{3}$

Središnje je istraživačko pitanje tematika općih pojavnih oblika pravno relevantne povrede pravila pružanja zdravstvene usluge, posebno u sklopu terapeutskog tretmana, s posljedicom građanskopravne odgovornosti za liječničku pogrešku. U tom su smislu istražene bitne komponente povrede medicinskoga standarda, čime za zdravstvenu ustanovu nastaje obveza naknade štete. Veliki dio rada odnosi se na prikaz praktičnih slučajeva ozbiljenja terapijske liječničke pogreške, kao i drugih nestandardnih pogreški u medicinskom tretmanu.

U znanstvenom su radu primijenjene induktivna i usporedna i znanstvenoistraživačka metoda, dok je važan dio istraživanja presjek višegodišnje sudske prakse $\mathrm{u}$ hrvatskom i drugim pravnim sustavima. Odgovarajućom primjenom znanstvenoistraživačkih metoda utvrđeni su temeljni modaliteti povrede medicinskoga tretmana liječnika u hrvatskom i poredbenom pravu.

U radu se daje uvodno izlaganje o povredi medicinskoga standarda i liječničkoj pogrešci in genere te se nastavno izlaže temeljna klasifikacija dijagnostičkih, terapijskih i atipičnih liječničkih pogreški s pojavnim oblicima terapijske pogreške u medicinskoj i pravnoj praksi. Zaključnim razmišljanjima zaokružuje se, in ultima linea, opća tipologija pravno relevantnih štetnih radnji kojima se ostvaruje povreda medicinskog tretmana liječnika, u skladu s normama pozitivnog prava te prihvaćenim stajalištima sudske prakse.

\section{OPĆENITO O POVREDI MEDICINSKOG STANDARDA- LIJEČNIČKA POGREŠKA}

U pružanju usluge zdravstvenog tretmana od liječnika se očekuje primjena zahtijevanog zdravstvenoga protokola, odnosno standarda dužne pažnje u skladu s liječničkom strukom. Drugim riječima, u provođenju medicinskog tretmana liječnik je obvezan postupati s pažnjom dobroga stručnjaka (gospodarstvenika) u korelaciji s normama pozitivnog prava koje utvrđuju sadržaj pojmova „kvaliteta zdravstvene zaštite" i ,standard kvalitete zdravstvene zaštite". ${ }^{4} \mathrm{U}$ isto vrijeme poredbeni pravni poredci koriste sintagme ,razuman liječnički standard” koji proizlazi iz pravila zdravstvenog umijeća - ars medica, standard bonus pater familias ili reasonably competent doctor i dr. ${ }^{5}$

U teoriji se naglašava da svaki zdravstveni postupak može biti poduzet contra legem artis, odnosno kao skrivljeno, nesavjesno postupanje liječnika ako je medicinski tretman poduzet bez odgovarajućeg stupnja stručne vještine, pažnje

Clinical Orthopaedics and Related Research 471, br. 10 (2013): 3355.

3 Francesco Traina, „Medical Malpractice: Experience in Italy“, Clinical Orthopaedics and Related Research 467, br. 2 (2008): 434.

4 Pojmovi se odnose na rezultat mjera koje se trebaju poduzimati u skladu sa suvremenim spoznajama u zdravstvenim postupcima, a koje osiguravaju najviši mogući povoljan ishod liječenja i smanjenje rizika za nastanak neželjenih posljedica na zdravlje ljudi (čl. 3. Zakona o kvaliteti zdravstvene zaštite i socijalne skrbi, Narodne novine, br. 124/11.).

5 Santo Davide Ferrara, Rafael Boscolo-Berto i Gudio Viel, ur. Malpractice and Medical Liability (Berlin: Springer Science and Business Media, 2013.), 77. 
i kompetencije ili kao propuštanje poduzimanja radnji koje su medicinski zahvat i koje su trebale biti obavljene u skladu s pravilnim i opravdanim standardom dužne pažnje te stručnim vještinama temeljenima na kompetentnom profesionalnom mišljenju liječnika. ${ }^{6}$ Liječnička se pogreška može očitovati i u bilo kojem drugom nesvrsishodnom postupku liječnika, kao i u vidu zakašnjeloga medicinskog tretmana. ${ }^{7}$ Prema stajalištu sudske prakse u Republici Hrvatskoj, liječnici u ispunjavanju obveza iz svoje profesionalne djelatnosti trebaju postupati s pažnjom dobroga stručnjaka. Zbog toga je za ocjenu odgovornosti liječnika odlučno utvrditi je li liječnik postupao suprotno pravilima i metodama rada zdravstvene struke, odnosno suprotno znanstvenim spoznajama kojima se ugrožava život i zdravlje ljudi. ${ }^{8}$ Hrvatska je praksa nepodijeljena u stajalištu da je liječnik građanskopravno odgovoran ako pri pružanju zdravstvene usluge nije postupao s pažnjom koja se može očekivati od iskusnog i savjesnog medicinara istoga ranga u konkretnim okolnostima i u stajalištu da su za ocjenu odgovornosti odlučujuće činjenice je li liječnik postupao s dužnom pažnjom, tj. s pažnjom iskusnog i savjesnog medicinara u konkretnim okolnostima. ${ }^{9}$

Sa stajališta medicinske znanosti u Republici Hrvatskoj liječnička pogreška stricto sensu je stručna pogreška - promašaj, zbog kojeg planirano liječenje nije završilo kako je bilo predviđeno, primjena pogrešnog plana u svrhu liječenja ili štetni događaj - oštećenja prouzročena liječenjem, koja mogu biti preventabilna (uključujući nemar i nepažnju) i neizbježna (pogreška uređaja, anafilaktički šok i sl.), odnosno događaj u kojem dolazi do nenamjerne i nepoželjne štete za bolesnika koja mu je nanesena medicinskim postupanjem, što produlje liječenje ili prouzroče oštećenja organizma koje je povezano s trajnom ili prolaznom nesposobnosti ili u najgorem slučaju prouzroče smrt. ${ }^{10}$ Ako se liječnička pogreška promatra s kliničkoga gledišta, tada se kvalificira kao vitium artis, dok se s aspekta sudske medicine upozorava da medicinski tretman nije ispravno obavljen. ${ }^{11}$

\section{MODALITETI POVREDE MEDICINSKOG TRETMANA LIJEČNIKA}

\subsection{Klasifikacija liječničkih pogreški}

Liječničke pogreške uobičajeno se klasificiraju s obzirom na pojedine stadije dijagnostičko-terapijskog tretmana. Općenito se mogu prepoznati kao pogreške

6 Dieter Giesen, International Medical Malpractice Law: A Comparative Law Study of Civil Liability Arising from Medical Care (Tübingen - Dordrecht: Mohr, Nijhoff, 1988.), 105.

7 Harald Franzki, ,Behandlungsfehler“, u: Lexikon Medizin, ur. Albin Eser, Markus von Lutterotti i Paul Sporken (Ethik, Basel-Wien: Recht, Freiburg, 1989.), 191.

8 Županijski sud u Rijeci, Gž. 2380/2016-4.

9 Županijski sud u Bjelovaru, Gž. 995/2016-2.

10 Egidio Ćepulić, „Profesionalna odgovornost liječnika i skandinavski model osiguranja liječnika (no fault compensation system)“, u: Profesionalna odgovornost liječnika, ur. Tatjana Josipović. Zagreb: Hrvatska liječnička komora, 2007.

11 Josip Škavić i Dušan Zečević, „Komplikacija i greška - sudskomedicinski pristup“, u: Građanskopravna odgovornost u medicini: okrugli stol, ur. Jakša Barbić (Zagreb: HAZU, 2008.), 24. 
$\mathrm{u}$ aktivnom liječenju i pogreške u postoperativnoj fazi, odnosno kao pogreške aktivnoga postupanja te odbacivanje neophodnog postupka, ${ }^{12}$ na grube ili teže i lakše; na taktičke i tehničke; na opće, elementarne, pogreške u organizaciji rada, ${ }^{13}$ pogreške $\mathrm{u}$ vođenju medicinske dokumentacije i pogreške u ponašanju medicinskog osoblja $u$ zdravstvenim ustanovama. ${ }^{14}$

U pravnoj se literaturi ističe gledište prema kojem se liječničke pogreške mogu temeljno klasificirati u šest grupa: (1) liječničke pogreške izravno štetne za pacijentovo zdravlje, (2) liječničke pogreške neprimjerene $u$ odnosu na stanje pacijentova zdravlja, (3) liječničke pogreške koje su pretjerane s obzirom na pacijentovo zdravlje, (4) potpuno nerazumne liječničke pogreške, (5) posljedice liječničkih pogrešaka koje su rezultat apliciranja određenih dijagnostičko-terapijskih postupaka utemeljenih na pogrešnoj dijagnozi koja se mogla izbjeći, ili (6) posljedice liječničkih pogrešaka koje su nastupile zbog činjenice da je liječnik propustio obavijestiti pacijenta o prirodi svojega zdravstvenog stanja ili bolesti. ${ }^{15}$ Također, u dijelu pravne teorije liječničke se pogreške razlikuju na pogreške u dijagnozi i terapiji; pogreške kod neinvazivnih zahvata te invazivnih zahvata; ${ }^{16}$ pogreške koja se tiče posjećivanja i medicinske obrade, liječenja pacijenta; pogreške u dijagnozi, pogreške u komunikaciji između liječnika i pacijenta te medicinskog osoblja itd. ${ }^{17}$

U skladu s naznačenim stajalištima liječničke pogreške bi se na temelju kriterija modo et forma mogle podijeliti na dvije grupe - dijagnostičke i terapijske liječničke pogreške, od kojih svaka grupa ima svoje podoblike. Primjerice, kada je u pitanju terapijska liječnička pogreška ona po prirodi medicinskoga protokola obuhvaća, tzv. komunikacijske liječničke pogreške koje nastaju zbog nepravilne komunikacije između subjekata medicinskoga tretmana, bez obzira na aktivni ili pasivni oblik ostvarenja, a pojavljuju se u sklopu šireg tijeka medicinske terapije. ${ }^{18}$ Medicinska i pravna praksa poznaju zaseban modalitet liječničkih pogreški sui generis koje se mogu označiti pojmom nestandardne (atipične) liječničke pogreške, a koje se faktično uozbiljuju kao slučajne povrede $\mathrm{u}$ sklopu medicinskoga tretmana prouzročene nedostatnom pozornosti liječnika i/ili medicinskog osoblja, poput propusta da se osigura odgovarajuća statika medicinskih transportnih sredstava sl. ${ }^{19}$

U kontekstu razrade tipologije liječničkih pogreški suvremena sudska medicina

12 Ada Polajnar Pavčnik, „Zaplet, napaka in pravne posledice“, u: Medicina in pravo: sodobne dileme, ur. Jelka Reberšek Gorišek et al. (Maribor: Pravna fakulteta - Splošna bolnišnica, 2006.), 219.

13 Petar Klarić, „Odgovornost zdravstvene ustanova i zdravstvenih djelatnika za štetu (Prvi dio)“, Hrvatska pravna revija 1, br. 8 (2001): 35 .

14 Jakov Radišić, Odgovornost zbog štete izazvane lekarskom greškom u lečenju i u obaveštavanju pacijenta (Beograd: Nomos, 2007.), 84.

15 Giesen, International Medical Malpractice Law: A Comparative Law Study of Civil Liability Arising from Medical Care, 72.

16 Ivica Crnić, Odgovornost liječnika za štetu (Zagreb: Organizator, 2009.), 54.

17 Andrew Grubb i Judith Laing, Principles of medical law (Oxford: Oxford University Press, 2004.), 406.

18 Hrvoje Vojković, Građanskopravna odgovornost za liječničku pogrešku, doktorska disertacija (Zagreb: Pravni fakultet Sveučilišta u Zagrebu, 2013.), 156.

19 Vojković, Građanskopravna odgovornost za liječničku pogrešku, 201. 
utvrdila je metode i kriterije procjene u sklopu postupka rekonstrukcije i potvrde stvarnog ponašanja liječnika i zdravstvenog osoblja tijekom medicinskoga tretmana. Prema prihvaćenom protokolu od stručnjaka sudske medicine očekuje se da obavi ex post analizu ponašanja liječnika u odnosu na sve zahtjeve koje standard medicinskoga tretmana postavlja te mu se nastavno stavlja u zadatak procjena ispravnosti različitih dijagnostičkih, prognostičkih i terapeutskih faza u cilju istraživanja liječničke pogreške. ${ }^{20}$

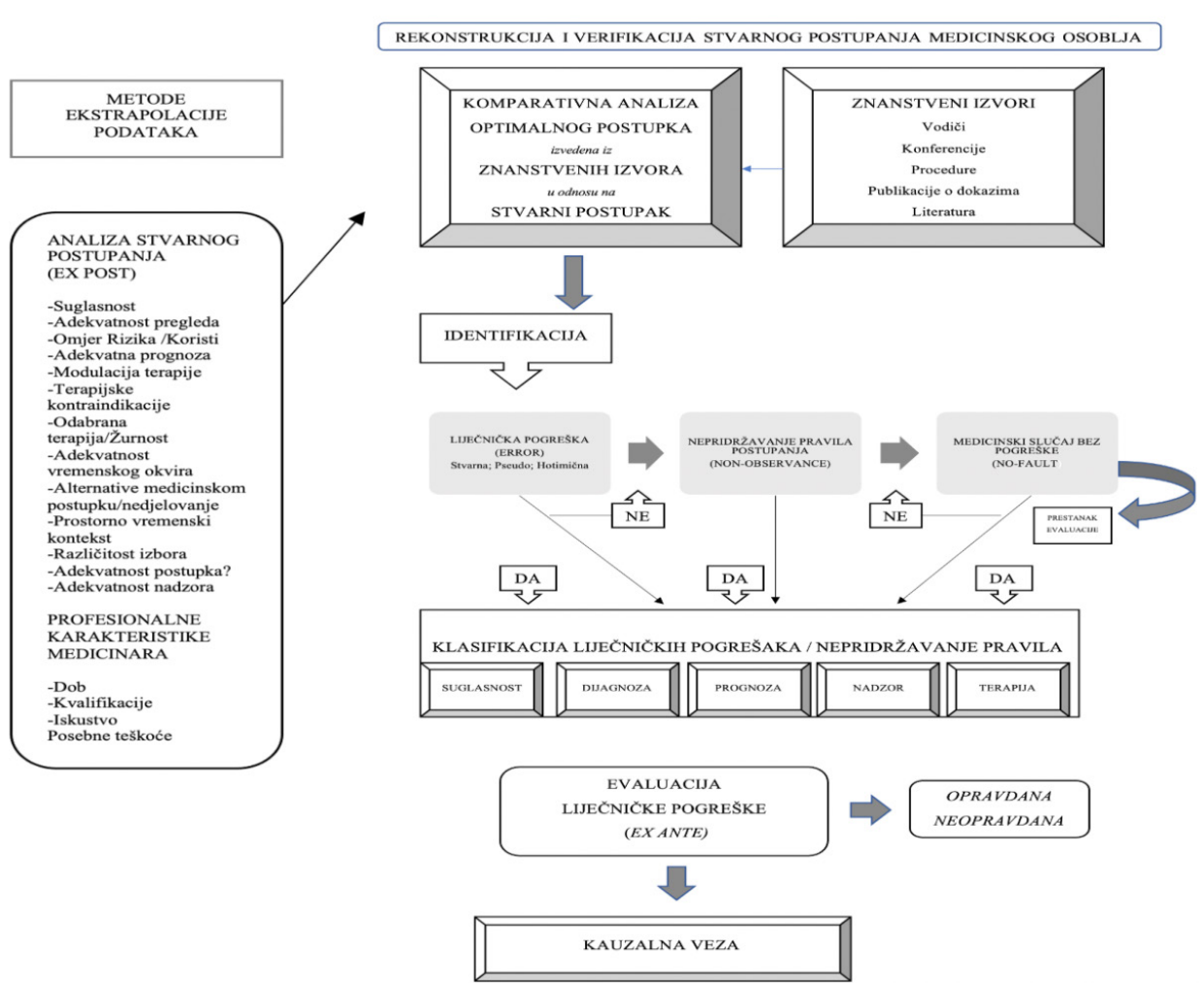

Slika 1. Rekonstrukcija i verifikacija stvarnoga postupanja medicinskog osoblja ${ }^{21}$

Zaključno valja napomenuti da se u medicinskoj praksi, osim opisanog oblika liječničke pogreške prouzročene nestručno provedenim medicinskim tretmanom (liječnička pogreška stricto sensu), konkretno odstupanje od standarda medicinskog tretmana može očitovati u činjenici da je poduzet bez valjanoga pristanka pacijenta, zbog čega je pretrpio povredu prava na tjelesni integritet (liječnička pogreška in extenso sensu). ${ }^{22} \mathrm{~S}$ pravnog i medicinskog aspekta riječ je o dva neovisna modaliteta

20 Ferrara, Boscolo-Berto i Viel, Malpractice and Medical Liability, 265.

21 Prilagođeno prema Santo Davide Ferrara, Rafael Boscolo-Berto i Gudio Viel, ur. Malpractice and Medical Liability (Berlin: Springer Science and Business Media, 2013.), 265.

22 Vojković, Građanskopravna odgovornost za liječničku pogrešku. Doktorska disertacija (Zagreb: Pravni fakultet Sveučilišta u Zagrebu, 2013.), 152. 
štetnih radnji koji su svaki za sebe samostalna osnova za naknadu štete. ${ }^{23}$ Bitno je naglasiti da povreda prava osobnosti (informirani pristanak) postoji neovisno o mogućnosti da je u konkretnoj situaciji samovoljni medicinski tretman proveden $\mathrm{u}$ svemu prema pravilima zdravstvene struke te ne predstavlja male praxis.

\subsection{Liječnička pogreška u terapiji (terapijska liječnička pogreška)}

Terapijska liječnička pogreška može se s obzirom na modus operandi podijeliti u dvije osnovne grupe. U prvom slučaju do liječničke pogreške dolazi kada se terapijski postupak provodi na način koji nije u skladu s pravilima zdravstvene struke, kao suboptimalni tretman contra legem artis u aktivnom obliku pogreške. U drugom slučaju do ozbiljenja pogreške dolazi zbog stručnih propusta kada posljedično izostaje terapijski postupak koji zahtijeva važeći medicinski standard u pasivnom obliku pogreške.

U pravnoj se teoriji navodi da prvu grupu slučajeva karakterizira svjesno ili nesvjesno odstupanje od medicinskog standarda, kao što su situacije liječenja teško bolesnih pacijenata isključivo lijekovima komplementarne medicine, obrada otvorene infekcije bez aplikacije antibiotika, već samo previjanjem itd. Za drugu je grupu pogreški tipično da liječnik nije svjestan da poduzeti medicinski tretman odstupa od pravila medicinske struke, poput, primjerice, slučajeva zaostaloga medicinskog instrumenta u tijelu pacijenta, amputacije pogrešnog uda, prekomjernog izlaganja medicinsko-tehničkim postupcima, davanja injekcije u pogrešnu žilu i dr. ${ }^{24}$

Ako bi se tijekom poduzetoga terapijskog tretmana utvrdila medicinska praznina u praksi, tada treba procijeniti je li popunjavanje izvjesne medicinske praznine razuman rizik, što posebno vrijedi za situacije kada se svjesno preuzima rizik od teške opasnosti. ${ }^{25} \mathrm{~S}$ obzirom na navedeno, eventualno popunjavanje stručnih praznina treba proizlaziti iz pravila važećega medicinskog standarda, jer će odsustvo liječničke pogreške i uzročne veze biti samo onda kad se štetna posljedica nije mogla svladati usprkos tome što se postupalo s potrebnom pažnjom u skladu s medicinskim standardom. ${ }^{26}$

\subsubsection{Pojavni oblici liječničke pogreške u terapiji u hrvatskoj praksi te ad comparandum}

Istraživanje hrvatske i usporedne prakse pokazalo je na neke gotovo dramatične slučajeve počinjenja terapijskih liječničkih pogreški s redovito teškim zdravstvenim posljedicama po zdravlje i život pacijenta. Tako se može izdvojiti znameniti slučaj iz kanadske prakse kada je zbog propusta dužne pozornosti pacijent primio fatalnu dozu adrenalina umjesto novokaina te je preminuo, ${ }^{27} \mathrm{kao}$ i slučaj iz njemačke prakse kada

23 VSRH, Rev 1022/2015-3.

24 Giesen, International Medical Malpractice Law, 138.

25 Vidi predmet: Hucks v. Cole (1968.) [1993] 4 Med LR 393, prema: Grubb i Laing, Principles of medical law 414.

26 VSRH, Rev 876/2006-2.

27 Budgen v. Harbour View Hospital (1947.) i Pollard v. Chipperfield (1952.). 
je liječnik radi manjka fokusa tijekom provođenja terapije pacijentu ordinirao dozu lijeka koja je višestruko premašivala dopuštenu dozu. ${ }^{28} \mathrm{U}$ novijoj hrvatskoj praksi može se uputiti na slučaj kada je pri punkciji jetre liječnik iglom prošao kapsulu, što je dovelo do krvarenja ispod čahure jetre te je pacijentica posljedično morala prekinuti antikoagulantnu terapiju, što je nepovoljno utjecalo na daljnji tijek liječenja njezine osnovne bolesti (progresija venozne tromboze i plućna embolija), ${ }^{29}$ kao i na situaciju kada je liječnik operater postavio klipse na pogrešno mjesto - na žučni vod umjesto na krvnu žilu jer nije prepoznao anatomske strukture:

...pa kada je nastavio zahvat prema metodi kojom ga je započeo sasvim sigurno $d a$ nije postupao s dužnom pažnjom, odnosno s pažnjom iskusnog $i$ savjesnog medicinara jer se u protivnom ne bi dogodilo to da je klipsu postavio na pogrešnu anatomsku strukturu, odnosno umjesto na krvnu žilu na žučni vod..$^{30}$

U drugom starijem predmetu sud je utvrdio terapijsku pogrešku jer je do ispadanja zuba došlo zbog nepravilnog izvođenja intubacije, s obzirom na to da je zub izvađen mehanizmom poluge, što je protivno pravilima struke jer se laringoskop ne naslanja na zube. ${ }^{31}$ Zasigurno medijski najistaknutiji slučaj u hrvatskoj pravnoj i medicinskoj praksi jest slučaj Maškarin koji je uvelike utjecao na jačanje svijesti šire javnosti o neophodnosti poštovanja medicinskoga standarda u najboljem interesu pacijentova zdravlja, kao i o temeljnim pravima pacijenata koja proizlaze iz provođenja medicinskoga tretmana. Naime, u tom je slučaju nakon operacije slijepog crijeva zbog liječničke pogreške došlo do komplikacija, zbog čega je pacijentu, tada dvadesetogodišnjaku, amputirana lijeva noga u visini donje trećine natkoljenice. Sud je utvrdio teška ireverzibilna oštećenja mladićevog zdravlja s odlučnim utjecajem na kvalitetu njegova života u budućnosti te je u skladu s time odmjerio pravičnu novčanu naknadu:

...utvrđeno je da je tijekom dugotrajnog liječenja i fizikalne terapije tužitelj trpio brojne neugodnosti (injekcije, infuzije, transfuzije, previjanja, RTG snimke, njegu dekubitusa, njegu traheotomijske kanile, obavljanje nužde u krevetu, nošenje urinskog katetera, brojne operacije); da je tijekom liječenja i operativnog zahvata tužitelj trpio jake bolove u trajanju od 30 dana, bolove srednjeg intenziteta u trajanju od 90 dana, bolove manjeg intenziteta u trajanju od šest mjeseci; da primarni strah nije postojao jer je tužitelj bio u općoj anesteziji, sekundarni strah zbog zabrinutosti za ishod liječenja jakog intenziteta da je trajao 40 dana, srednjeg intenziteta 100 dana te lakog intenziteta 200 dana; da zaostale posljedice koje se očituju u gubitku lijeve noge u visini donje trećine lijeve natkoljenice, oštećenju desne potkoljenice s gubitkom mišićne mase od oko $70 \%$, oštećenju desnog peronealnog živca $20 \%$, glutealnog $5 \%$ i femoralnog $8 \%$, u ograničenim pokretima stopala desne noge te mogućnost hodanja samo s protezom uz pomoć štaka, smanjuju životnu aktivnost tužitelja u omjeru od $85 \%$; da kod tužitelja zbog gubitka lijeve natkoljenice, zaostalih izrazito trofičnih promjena na desnoj nozi te primjetnom šepanju, postoji naruženost

28 Giesen, International Medical Malpractice Law: A Comparative Law Study of Civil Liability Arising from Medical Care, 142.

29 VSRH, Rev 494/2012-2.

30 Županijski sud u Bjelovaru, Gž 995/2016-2.

31 Općinski sud u Slavonskom Brodu, P-1320/98-32. 
jakog stupnja; da je tužitelju trajno potrebna primjena natkoljenične proteze uz korištenje štaka; da se zbog nastalih posljedica tužitelju život nepovratno promijenio jer se više neće moći baviti sportom, obavljati poslove zanimanja za koje se školovao te će se susretati s brojnim ograničenjima u kretanju. ${ }^{32}$

Uvodno je napomenuto da se terapijska liječnika pogreška katkad pojavljuje u vidu zaostaloga stranog tijela - medicinskog instrumentarija, vate, vrha injekcije, brisa u trbuhu i sl..$^{33}$ Primjerice, u postupku probijanja kosti uslijedio je lom vrha bušilice, pri čemu je liječnik prelomljeni dio namjerno ostavio u tijelu pacijenta te ga o tome nije izvijestio. Nakon nekoga vremena pacijent je sve više osjećao bol na mjestu ostavljenoga stranog tijela te se podvrgnuo novom kirurškom zahvatu u drugoj zdravstvenoj ustanovi i pritom mu je nađen zaostali vrh bušilice. U kasnijem odštetnopravnom postupku pacijent je ostvario pravo na naknadu štete zbog grube liječničke pogreške koja se kvalificirala kao „neshvatljiv propust liječnika”. ${ }^{34}$

Međutim, prema općem stajalištu njemačke sudske prakse u tim i sličnim slučajevima, kada je pitanje kauzaliteta činjenično nedvojbeno (napose u kontekstu anglosaksonskoga prava u skladu s načelom res ipsa loquitur), ${ }^{35}$ liječnik neće via facti biti građanskopravno odgovoran za terapijsku pogrešku ako se utvrdi da je postupao prema traženom medicinskom standardu u određenoj vrsti terapijskoga postupka. U konkretnom je slučaju izneseno gledište da samo ostavljanje stranoga tijela na kraju operacije u masnom tkivu, gdje ne može izazvati nikakve komplikacije, nije pogreška u liječenju jer mogućnost da do prijeloma igle dođe opći je rizik operacije, s kojim pacijent treba računati. ${ }^{36}$

Kada su u pitanju rizični, kontraindicirani operativni postupci od liječnika se očekuje rezerviran i konzervativan pristup u nastojanju da se dodatno ne komplicira zdravstveno stanje pacijenta. Kao dobar primjer može se uzeti slučaj iz američke prakse kada je kirurški postupak prouzročio štetu u vidu amputiranoga palca jer je pacijent bio izložen velikom riziku od razvoja infekcije tkiva. ${ }^{37}$ Medicinski tretman može biti obilježen dvojbom o jednoj ili više terapijskih metoda koje se primjenjuju u medicinskoj praksi. Kao opće pravilo, na koje upozorava sudska praksa, može se uzeti da je liječnik obvezan odabrati metodu koja je općeprihvaćena u određenom zdravstvenom sustavu, i to bez obzira na činjenicu postoji li eventualno novorazvijena metoda koja nije dostupna u vrijeme provođenja medicinskog tretmana:

...tuženik je dokazao da je u konkretnom slučaju i konkretnim okolnostima medicinsko osoblje tuženika postupalo po pravilima struke te da nije bilo pogreške ili propusta kako u odabiru metode anesteziranja, tako pripremi operacije, tijeka uvođenja $u$ anesteziju, te u postupku reanimacije. Naime, kako je to utvrđeno temeljem nalaza vještaka, $u$ to je vrijeme ova metoda anestezije bila općeprihvaćena

32 VSRH, Rev x 848/2017-2.

33 Vidi predmet: Richardson v. Winchester \& Eastleigh Healthcare NHS Trust MLC 1552 (2008.).

34 Vrhovni zemaljski sud u Stuttgartu, Versicherungsrecht, br. 18/1989, 632-633.

35 Lat. „stvar govori sama za sebe“.

36 Vrhovni zemaljski sud u Oldenburgu, presuda od 20. prosinca 1994., Medizinrecht, br. 8/1995, 326-328.

37 Sudska praksa SAD-a, presuda drugostupanjskog suda (sudac Harry L. Carrico) u povodu žalbe na presudu Okružnog suda grada Portsmoutha u predmetu John R. Doherty vs. Debra J. Aleck. 
metoda koja se primjenjivala i na operacije carskog reza, dok se metoda epiduralne anestezije o kojoj je kao pravilnoj metodi govorila prof. dr. B.-W. u to vrijeme još nije primjenjivala u bolnicama u Republici Hrvatskoj (ova metoda počela se primjenjivati nakon 5 - 6 godina u nekim bolnicama u Zagrebu). ${ }^{38}$

Inače, u praksi operativnih zahvata katkad se mogu zabilježiti slučajevi kada je kirurški postupak proveden stručno, ali je do pogreške u terapiji ipak došlo naknadno, zbog propusta u postoperativnoj fazi. Tako je pacijentu nakon povrede ruke pružena stručna kirurška obrada, ali je radi neispravno postavljenog i preranoga skidanja gipsanoga zavoja prouzročeni pomak ulomaka i razvoj Sudeckovog sindroma. ${ }^{39} \mathrm{U}$ drugom je slučaju utvrđeno kako je u liječenju došlo do propusta jer je pacijentici skinuta imobilizacija nakon svega pet dana od ozljeđivanja, bez obzira na to što je na RTG slikama bila vidljiva avulzija (otkinuće kosti), zbog čega je njezina ozljeda zahtijevala imobilizaciju koljena longetom ili cirkularnim gipsom ukupno čak četiri do pet tjedana ili imobilizaciju koljena $\mathrm{u}$ ortozi. ${ }^{40}$ Liječničke se pogreške rjeđe pojavljuju u obliku kompleksa tipološki različitih konsekutivnih propusta tako da se na primarnu dijagnostičku pogrešku nadovezuje terapijska pogreška koja čini sukcesivni uzročni niz. Primjer takvoga oblika liječničke pogreške može se pronaći u hrvatskoj praksi:

...kod prvog operativnog zahvata na tužiteljici došlo je do ozljede glavnog žučnog voda, zbog čega se žuč izlila u trbušnu šupljinu. Do navedenog je došlo zbog propusta u liječenju, jer je tužiteljica otpuštena iz bolnice nakon prve operacije, a da pri tome nije prepoznato bolesno stanje iste, iako je trebalo biti, zbog čega je tužiteljica 4 dana poslije operacije preuranjeno puštena kući, da bi nakon ponovnog primitka u bolnicu već sljedećeg dana bila donesena odluka o ponovnom operativnom zahvatu. Upravo zbog neopravdano dugog perioda od ozljede glavnog žučnog voda do druge vitalne operacije nakupina žuči u trbuhu dovela je do upalnih reaktivnih promjena potrbušnice s trajnim posljedicama u vidu priraslica, smetnji u radu crijeva, djelomične zatvorenosti lumena crijeva s mogućnošću vitalnih komplikacija tijekom života, te oštećenja jetre, bubrega i CNS. Nadalje, utvrđuje se kao sljedeći propust s manje štetnim posljedicama kao što je potapanje T-drena pod kožu operativnim zahvatom, čime je onemogućeno propiranje drena zbog održavanja prohodnosti $R T G$ kontrola žučnih vodova $i$ olakšavanja rješavanja eventualnih opstrukcija $s$ infekcijom, zbog čega $i$ danas na tom mjestu postoji kronična recidivna fistula, a za kasnije vađenje drena da je bilo potrebno obaviti još jedan operativni zahvat. ${ }^{41}$

Terapijska liječnička pogreška relativno je znatnije zastupljena u obavljanju različitih ginekoloških zahvata te se nerijetko može ispoljiti u obliku neželjene perforacije maternice. Na to pokazuje primjer iz hrvatske prakse kada perforacija maternice nije bila prepoznata pri obavljanu zahvata, pa se kasnije nije mogla medicinski obraditi, što je u konačnici prouzročilo odstranjenje maternice kao štetnu posljedicu. ${ }^{42} \mathrm{U}$ poredbenoj se praksi ističe da perforaciju maternice koja bi se dogodila

38 VSRH, Rev x 232/2008-2.

39 Županijski sud u Slavonskom Brodu, Gž-294/03-2.

40 Županijski sud u Zagrebu, Gž 5602/2017-2.

41 VSRH, Rev 597/06-2.

42 VSRH, Rev 1584/1998-2. 
tijekom provođenja kiretaže i diletacije ne bi trebalo kvalificirati kao liječničku pogrešku jer je standardna pojava s obzirom na vrstu medicinskoga tretmana ${ }^{43} \mathrm{U}$ sličnom slučaju, nad pacijenticom je provedena sekcija zbog poroda, porod je uredno obavljen, ali je u nastavku medicinskoga tretmana došlo do komplikacija. Naime, pri sekciji je zakinuta maternica koja se morala ukloniti s jajnicima, tako da je pri uklanjanju maternice došlo do prešivanja lijevog uretera $s$ posljedičnim stvaranjem uretrovaginalne fistule do kojeg je došlo zbog liječničke pogreške. ${ }^{44} \mathrm{U}$ tom se kontekstu može uputiti na presudu iz novije hrvatske sudske prakse kojom je razmatrana građanskopravna odgovornost zbog loše vođenog poroda koji je prouzročio osobito teške zdravstvene posljedice - smrt djeteta i razdor maternice $s$ trajnom posljedicom nemogućnošću rađanja djece ubuduće:

...da je tuženica tijekom postupka priznala i osnovanost osnove tužbenog zahtjeva, da su prvo i drugotužitelji u vrijeme štetnog događaja bili zdravi i mladi ljudi u dobi od 24 godine $i$ da su krenuli u bolnicu u očekivanju poroda zdravog djeteta, jer im je takva činjenica potvrđena dva dana prije na kontrolnom pregledu kod tuženice, da su zbog štetnog događaja prvo i drugotužitelji pretrpjeli niz fizičkih i psihičkih posljedica, da je prvotužiteljica uz gubitak djeteta pretrpjela teške i trajne fizičke posljedice - razdor maternice, što je rezultiralo odstranjenjem iste, čime je prvotužiteljica uskraćena za daljnje materinstvo i onemogućena u ostvarenju života u mnogobrojnoj obitelji kakvu je priželjkivala, da je drugotužitelj, koji je neposredno prisustvovao cijelom porodu, bio izuzetno teško psihički pogođen s gubitkom djeteta i nemogućnošću budućeg roditeljstva, što se manifestiralo nemogućnošću kontaktiranja s ljudima uopće, izbjegavanjem ljudi, zatvaranjem u kuću, pokušajem suicida te višekratnom hospitalizacijom u psihijatrijskoj bolnici, da su se uslijed predmetnog štetnog događaja pokvarili i poremetili odnosi u braku. ${ }^{45}$

Bitno je naglasiti da terapijski postupak mora biti pravodoban s obzirom na okolnosti zdravstvenog slučaja in concreto. Ta obveza posebno dolazi do izražaja kada se tijekom medicinskoga tretmana očituje povećan rizik od nastupa komplikacija. Tako je usprkos očitim znakovima koji su upućivali na potrebu da se porod bez odgode obavi carskim rezom, i to odmah nakon ulaska u rađaonicu, došlo do zakašnjenja u provođenju zahvata, što je dovelo do nepopravljivog oštećenja zdravlja tako rođenog djeteta koje je mjesec dana kasnije preminulo. ${ }^{46}$ Također, kako se vidi u sljedećem slučaju iz domaće prakse, izostanak stalnoga nadzora i mogućnosti brze intervencije uvjetovao je nepravodobni terapijski postupak sa štetnom posljedicom:

No, upravo prema mišljenju i nalazu vještaka proizlazi da je kardiovaskularni arest jedna od poznatih komplikacija nakon anestezije, da su one moguće $i$ par sati nakon buđenja $i$ uspostavljanja kontakta s pacijentom te da je bitno osigurati kontinuirani nadzor $i$ mogućnost brze intervencije kvalificiranog liječnika anesteziologa i reanimatologa. U konkretnom slučaju proizlazi da je bolesnik transportiran na urološki odjel kada i nije bio potpuno razbuđen, a da je

43 Bovenzi v. Kettering (1991.), prema Grubb i Laing, Principles of medical law, 418.

44 VSRH, Rev 20/2009-2.

45 VSRH, Rev 1902/2013-2.

46 Općinski sud u Zagrebu, XXXV-Pn-3831/99. 
pravovremena reanimacija izostala jer nije postojao kontinuirani nadzor i mogućnost hitne intervencije kvalificiranog medicinskog osoblja. ${ }^{47}$

Provođenje terapijskoga postupka utemeljenog na općem medicinskom standardu uvijek je zahvat intuitu personae. Pritom je nužno uzeti u obzir sve posebne zdravstvene okolnosti na strani pacijenta koje su bitne za postizanje terapijskog cilja, a između ostalih i dob pacijenta jer pojedini terapijski zahvati mogu imati različite medicinske implikacije ovisno o pacijentovoj dobi. ${ }^{48}$ Postupanje suprotno tom pravilu može dovesti do liječničke pogreške, na što nastavno pokazuje presuda iz austrijske sudske prakse. Iako je bila riječ o rizičnoj trudnoći, jer je trudnica bolovala od kronične insuficijencije bubrega, a što je liječniku bilo poznato, nije ordiniran odgovarajući terapijski postupak prilagođen posebnim potrebama bubrežnog bolesnika, što je uvjetovalo zakašnjenjem poroda s posljedicom invaliditeta. ${ }^{49}$

$\mathrm{S}$ obavljanjem terapijskih zahvata, posebice u kirurgiji, u pravilu je povezan rizik on nastupa infekcije koja može biti uvjetovana nedostatnom razinom higijenskih uvjeta, izostankom sustava bolničke prevencije od nastanka i prijenosa zaraze, nepridržavanjem odgovarajućih medicinskih protokola vezano za sterilizaciju terapijskog instrumentarija, dvorane za izvođenje operativnih zahvata i sl. Od liječnika se očekuje i da pacijente ne izlažu riziku od zaraze osim ako je riječ o terapeutski opravdanom postupku kojim se ostvaruje svrha liječenja. U tom se smislu može spomenuti slučaj iz austrijske prakse kada je pri operaciji kuka koja nije bila neophodna došlo do infekcije, što je stvorilo potrebu za dodatnom operacijom. ${ }^{50}$ U drugom je predmetu iz austrijske sudske prakse razvoj bolničke infekcije bio prouzročen neodgovarajućim terapijskim postupkom tijekom hospitalizacije jer pacijentu nije aplicirana odgovarajuća terapijska doza antibiotika te nije poduzeto višekratno artroskopsko ispiranje kako bi se spriječilo širenje infekcije..$^{51} \mathrm{U}$ pogledu postoperativnih infekcija u pravnoj se teoriji upozorava da ona per se nije dokaz liječničke pogreške, ali se istodobno od liječnika zahtijeva da promptno dijagnosticira simptome infekcije koja bi se mogla razviti kao posljedica operativnog zahvata te da započne odgovarajući medicinski tretman. ${ }^{52} \mathrm{U}$ slovenskoj sudskoj praksi razmatrana je odgovornost za naknadu štete u slučaju smrti pacijenta koja je bila prouzročena infekcijom zlatnoga stafilokoka u okolnostima nesterilne njege:

Bolnica odgovara za štetu koja je nastala zbog bakterijske infekcije bolesnika, ako je uzrok nesterilna njega. Naime, pacijent je bio urgentno operiran zbog ukliještene trbušne kile, a iako je operacija bila uspješna, bolesnikovu je smrt uzrokovala upala trbušne mrene zbog infekcije s bakterijom zlatni stafilokok koja je unesena u bolesnikovo tijelo zbog nesterilnog rada liječničkog osoblja. ${ }^{53}$

Infekcija može biti prouzročena transfuzijom krvi, inseminacijom ili transplantacijom organa donora. Povreda standarda medicinskoga tretmana neće

47 VSRH, Rev 876/2006-2 od 10. siječnja 2007.

48 VSRH, Rev 829/06-2.

49 Vrhovni sud Austrije, 40b75/08w.

50 Vrhovni sud Austrije, 90b79/07v.

51 Vrhovni sud Austrije, 6Ob75/08k.

52 Grubb i Laing, Principles of medical law, 422.

53 Vrhovni sud Republike Slovenije, II Ips 524/2004. 
nastupiti ako je u postupku transfuzije krvni pripravak nabavljen od ovlaštene ustanove koja nije bila obvezna dodatno ispitati krvni pripravak. ${ }^{54}$

U skladu s citiranim stajalištem moglo bi se per analogiam zaključiti da neće postojati građanskopravna odgovornost u slučaju transplantacije infektivnog organa ili inseminacije ako su organ ili sjemena tekućina pribavljeni prema posebnom medicinskom protokolu, tj. od ovlaštene ustanove, što isključuje potrebu daljnje analize tkiva. U hrvatskom medicinskom pravu propisuje se da je u svrhu ranog otkrivanja izvora zaraze i putova prenošenja zaraze neophodno obaviti ispitivanje krvi davatelja te stanica, tkiva, organa za presađivanje i sjemene tekućine na prisutnost biljega zaraznih bolesti, a to ispitivanje obavljaju nadležni zavodi za javno zdravstvo. ${ }^{55}$ Medicinska praksa poznaje situacije kada se krvni pripravci izravno prikupljaju od zdravstvene ustanove, a te je pripravke potrebno posebno ispitati prije transfuzije. Nastavno na to se izdvaja predmet iz prakse hrvatskih sudova kada je utvrđeno da nije poštovan utvrđeni protokol te je pacijent, inače na redovnom liječenju zbog perforacije čira, primio transfuziju neispitane krvi prikupljene od volontera te se posljedično zarazio virusom hepatitisa C. U postupku je utvrđena odgovornost za naknadu štete jer je bolnica prikupljenu krv pripremila za upotrebu i dala pacijentu, a pritom nije postupila u skladu s odredbom čl. 13. st. 1. t. 6. Zakona o zaštiti pučanstva od zaraznih bolesti, odnosno bolnica je propustila ispitati krv davatelja na prisutnost markera virusne žutice tipa B i C, pa je zbog bolničkoga propusta pacijent zaražen hepatitisom C. ${ }^{56}$

Osim obveze ispitivanja krvnih pripravaka i drugoga, u njemačkoj se praksi upozorava kako se pacijent uvijek treba upozoriti na opći rizik od infekcije AIDS-om $\mathrm{i}$ hepatitisom te na varijantu autologne transfuzije.$^{57}$ Provedeno istraživanje poredbene prakse upozorava na slučaj kada je pacijent transfuzijom zaražene krvi obolio od HIV-a te je naknadno zarazio i suprugu prakticirajući s njom seksualne odnose bez zaštite. U pokrenutom odštetnopravnom postupku sud je utvrdio liječničku pogrešku koja se sastojala u izostanku valjanoga terapeutskog obavješćivanja na okolnost rizika od moguće infekcije, a čime su per consequens prouzročene obje štetne posljedice zaraza pacijenta i njegove supruge..$^{58}$ Posebna jr situacija kada su nositelji zaraznih bolesti liječnici. Naime, u tim se slučajevima zahtijeva da se daljnja liječnička praksa provodi tako da se spriječi eventualna zaraza. Ako liječnici svjesno nastavljaju praksu bez nužnih modifikacija, to znači da izlažu pacijente neprihvatljivom riziku od infekcije. ${ }^{59}$

Terapijska liječnička pogreška može biti i propust dužnog nadzora nad obavljanjem medicinskoga tretmana liječnika koji raspolaže s manje stručnog znanja

54 VSRH, Gzz 249/03-2.

55 Čl. 13. st. 1. t. 6 i st. 2. Zakona o zaštiti pučanstva od zaraznih bolesti, Narodne novine, br. 79/07., 113/08., 43/09., 130/17., 114/18., 47/20., 134/20.

56 VSRH, Rev 1918/01-2.

57 Savezni vrhovni sud Njemačke, Medizinrecht, br. 3/1992, 159-161.

58 Pittman Estate v. Bain (1994.) 112 DLR (4th) 257, prema: Grubb i Laing, Principles of medical law, 414.

59 Grubb i Laing, Principles of medical law, 425. 
i vještine. ${ }^{60}$ Ipak, neće biti ostvarene pretpostavke građanskopravne odgovornosti za štetu ako je terapijski postupak proveden u skladu s pravilima medicinske struke, kao u slučaju koji se navodi u nastavku:

...da je predmetnu pretragu izveo samostalno specijalizant, bez nadgledanja specijaliste te da činjenica da je specijalizant obavio takav zahvat na rizičnom pacijentu nije u uzročno posljedičnoj vezi s krajnjim nastupom smrti pacijenta, odnosno da je sam zahvat biopsije prostate proveden po pravilima struke te da prilikom tog zahvata nije učinjena pogreška ${ }^{61}$

U širem terapijskom tretmanu od liječnika se očekuje da redovito posjećuje pacijenta te da stalno brine o njegovu zdravlju, što posebno uključuje postoperativni tretman pacijenta. Poredbena praksa upozorava na slučaj kirurga koji je nakon provedene operacije otpustio pacijenta, ali bez terapeutskog obavješćivanja o mogućnosti ostvarivanja uobičajene medicinske komplikacije u vidu krvarenja i potrebi da ga o tome žurno izvijesti. ${ }^{2}$

Tijekom pružanja terapijskoga tretmana liječnici se moraju uzajamno koordinirati te predvidjeti sve realne medicinske rizike i one koje proizlaze iz samostalnog djelovanja u zajedničkom postupanju i nove rizike koji se po prirodi postupka stvaraju kombinacijom terapijskih mjera, posebno kod interdisciplinarnih invazivnih terapijskih postupaka. U predmetu iz njemačke prakse razmatran je slučaj kada je upravo radi izostanka koordinacije između kirurga i anesteziologa dvogodišnji dječak tijekom operacije oka zadobio teške opekotine od termokautera koji je u jednom trenutku razvio snažan plamen. Sud je zauzeo stajalište o liječničkoj pogrešci u terapiji usprkos činjenici da nije utvrdio pojedinačne liječničke propuste, već je smatrao da su obojica krivi jer svoj rad nisu uskladili dogovorom prije operacije, pri čemu je rizik od nastanka plamena obojici bio poznat i predvidljiv s obzirom na činjenicu zapaljivosti kisika. ${ }^{63}$

\subsubsection{Posebno o komunikacijskoj terapijskoj pogrešci}

Liječnička se pogreška u terapiji katkad javlja u obliku komunikacijske pogreške koja nastaje između subjekata medicinskoga tretmana, liječnika i pacijenta, odnosno liječnika i zdravstvenog osoblja. Najčešći su slučajevi kada liječnik zbog manjka koncentracije ili nedostatne stručne brige izvijesti pacijenta o važnim okolnostima njegova zdravstvenog stanja ili kada među liječnicima, odnosno između liječnika i medicinskog osoblja izostane odgovarajuće informiranje. Do toga u pravilu dolazi zbog nedostatne interne organizacije zdravstvene ustanove, tj. svojevrsnog „šuma” u komunikacijskom kanalu. Posljedice takve pogreške mogu se očitovati u vidu nepravodobnog prikupljanja medicinske dokumentacije, kašnjenja u dostavi krvnih pripravaka i slično, što su štetne posljedice u blažoj varijanti. Istodobno, kako je pokazalo istraživanje hrvatske i usporedne prakse, krajnje posljedice tog modusa terapijske pogreške mogu rezultirati tragičnim posljedicama. Primjer je

60 Vidi predmet: Greenhorn v. South Glasgow University Hospitals NHS Trust MLC 1556 (2008.).

61 VSRH, Rev 3010/2014-2.

62 Vidi predmet: Corder v. Banks (1960.), prema: Grubb i Laing, Principles of medical law, 407.

63 Savezni vrhovni sud Njemačke, Medizinrecht, br. 7/1999, 321-323. 
slučaj u kojem je pacijent preminuo jer mu je umjesto lokalnog anestetika prokaina zabunom intravenozno apliciran kokain. Naime, mladi je specijalizant krivo čuo liječnika specijalistu koji mu je dao telefonske upute. Pritom farmakolog nije smatrao potrebnim dodatno ispitati narudžbu kokaina, a ni liječnik specijalist nije posebno provjerio jesu li operacijske pripreme izvršene u skladu s njegovim nalogom. ${ }^{64} \mathrm{U}$ drugom je slučaju liječnik izdao recept astmatičaru, ali potpis nije bio sasvim čitjiv, pa je farmakolog pogrešno pročitao amoksil umjesto daonil koji se koristi za liječenje dijabetesa. Tako je pacijent s astmom uzeo pogrešan lijek, odnosno lijek namijenjen dijabetičarima, što je prouzročilo hipoglikemiju te štetu u vidu trajnog oštećenja mozga. ${ }^{65}$

U pravnoj se teoriji ističe više kategorija obavješćivanja koja liječnik koji postupa lege artis redovito priopćava pacijentu. Ponajprije je riječ o obavješćivanju koje je pravna pretpostavka pacijentovoga pristanka na pojedini medicinski zahvat. Međutim, osim navedene vrste obavješćivanja treba razlikovati posebno terapeutsko obavješćivanje koja u svrhu zdravstvene sigurnosti liječnik treba dati pacijentu. ${ }^{66}$ U osnovi je riječ o informacijama koja za cilj imaju navesti pacijenta u kasnijoj terapijskoj fazi na ponašanje koje je u njegovom zdravstvenom interesu. ${ }^{67}$ Tako će liječnik rutinski upozoriti pacijenta na moguće nuspojave uzimanja nekog lijeka ili će ga obavijestiti o potrebi korekcije nekih životnih navika, trajno ili do okončanja terapijskog tretmana. Uz to, liječnik će povremeno provjeravati uzima li pacijent propisanu terapiju dok je na kućnoj njezi i dr. Tipičan slučaj iz njemačke prakse upozorio je na terapeutsku pogrešku liječnika jer pacijenta nije upozorio na rizik kontraindikacija povezan s primitkom visoke doze penicilina, zbog čega je pacijent pretrpio štetu. Naime, po povratku kući u stanju privremene dekoncentracije i smanjene sposobnosti za upravljanje osobnim vozilom, što su konkretne nuspojave uzimanja penicilina, pacijent je sletio s ceste i zadobio povrede od udara vozila u drvo. Sud je u kasnijem odštetnom postupku utvrdio građanskopravnu odgovornost zbog liječničke pogreške te je posebno istaknuo kako je „liječnik bio dužan ispitati na koji se način pacijent namjerava vratiti kući nakon što je primio terapiju penicilinom". ${ }^{68}$

Obveza davanja terapeutskih obavješćivanja nije ograničena samo na pacijenta, već se tiče širega kruga osoba koje s pacijentom ostvaruju redoviti i neposredan kontakt. Međutim, navedena se obveza odnosi samo na situacije kada bi zdravstveno stanje pacijenta ili primjena određene terapije mogli nepovoljno utjecati na zdravlje

64 Vidi predmet: Collins v. Hertfordshire County Council (1947.), prema: Grubb i Laing, Principles of medical law, 417.

65 Vidi predmet: Prendergast v. Sam \& Dee Ltd (1989.) 1 Med LR 36 (CA), prema: Grubb i Laing, Principles of medical law. Sudac je utvrdio da su sva tri tuženika odgovorna radi nemara te je $25 \%$ odgovornosti rasporedio na liječnika, dr. Millera, a $75 \%$ na farmaceuta i njegovu tvrtku. Odredio je odštetu od 137.647 GBP.

66 Radišić, Odgovornost zbog štete izazvane lekarskom greškom u lečenju $i$ u obaveštavanju pacijenta, 62.

67 Erwin Deutsch i Andreas Spickhoff, Medizinrecht, Arztrecht, Arzneimittelrecht, Medizinprodukterecht und Transfusionsrecht, 5. neue bearbeitete und erweiterte Aufl. (Berlin: Springer, 2003.), 142-143.

68 Deutsch, Spickhoff, Medizinrecht, Arztrecht, Arzneimittelrecht, Medizinprodukterecht und Transfusionsrecht, 154. 
trećih osoba (primjerice, neobavješćivanje obitelji pacijenta o rizicima teških pojavnih oblika duševnog oboljenja, izostanak upozorenja na okolnost mogućnosti prijenosa zarazne infekcije i sl.). U njemačkoj je praksi poznat slučaj kada je liječnik propustio obavijestiti roditelje cijepljenoga djeteta o rizicima zaraze trećih osoba napose s obzirom na tehnologiju vakcinacije jer je bila riječ o cjepivu sa živim oslabljenim virusima. Naime, kako je naglašeno u presudi, ,cijepljeno dijete izlučuje viruse više tjedana nakon cijepljenja, a opasnost da se njima zaraze treće osobe može se preduhitriti obavješćivanjem njegovih roditelja prilikom cijepljenja". Zbog povrede obveze terapeutskog savjetovanja navedeni komunikacijski propust sud je ocijenio kao terapijsku pogrešku, i to neovisno o činjenici da je statistička vjerojatnost ostvarenja rizika bila svega 1:15,5 milijuna procijepljenih:

Obavještavanje radi sigurnosti čini bitan sastojak liječničke zdravstvene službe. U slučaju kad je to potrebno, liječnik je, naime, dužan svojeg pacijenta podučiti o njegovom ponašanju u budućnosti, upozoriti i uputiti; mora poduzeti sve sto je u njegovoj moći da bi pacijenta sačuvao od štete koja prijeti njegovom zdravlju. Kad pacijent boravi u bolnici liječnik mu treba ukazati na opasnost zaraze koja dolazi od drugih pacijenata. Ako je sam pacijent izvor zaraze za članove svoje obitelji $i$ ostale treće osobe, onda ga valja na to upozoriti, radi zaštite onih koji s njim dolaze u tjelesni kontakt. ${ }^{69}$

\subsection{Nestandardne (atipične) terapijske pogreške}

Nestandardne liječničke pogreške su in esse, gotovo pa slučajne povrede medicinskoga standarda prouzročene ponajprije pomanjkanjem dužne pozornosti u širem okviru obavljanja zdravstvenoga tretmana. Riječ je sasvim atipičnim i neočekivanim pogreškama kojima se bez svijesti o tome oštećuje tjelesna sfera pacijenta, poput nenamjernog ozljeđivanja bolesnika padom $\mathrm{s}$ neučvršćenog operacijskog stola i slično. Iako se čini kao svojevrsna iznimka, usporedna njemačka praksa poznaje nemali broj slučajeva ostvarivanja navedenoga oblika terapijske pogreške. Tako se iznosi slučaj pacijentice koja je bolovala od Alzheimerove bolesti u uznapredovaloj fazi te je bila potpuno disfunkcionalna bez stalne skrbi stručnog osoblja. Naime, nije mogla jesti bez pomoći, i to redovito samo ,na žlicu”, ali je zbog propusta u nadzoru i pomoći kod konzumacije došlo da gušenja, jer je komad hrane zaostao u dušniku te do posljedične smrti. ${ }^{70} \mathrm{U}$ sljedećoj situaciji pacijent je u pokušaju da dođe do kupaonice pao i doživio nezgodu te je uzastopno pokušavao aktivirati svjetlosno-zvučni alarm, ali ni liječnik, ni medicinsko osoblje nisu odgovarali na upućeni zahtjev za pomoć. ${ }^{11}$

U hrvatskoj sudskoj prakse može se pronaći slučaj pada pacijentice na pod operacijske sale u trenutku prebacivanja s operacijskog stola na bolnička kolica, čime je došlo do tjelesne povrede, ${ }^{72}$ kao i na drugi slučaj kada je pacijent preminuo zbog pada s kolica jer njegov prijevoz nije bio obavljen po pravilima medicinske

69 Savezni vrhovni sud Njemačke (BGH), Medizinrecht, br. 1/1995, 25-29.

70 Savezni vrhovni sud Njemačke (BGH), Medizinrecht, br. 1/1995, 25-29.

71 Savezni vrhovni sud Njemačke (BGH), Medizinrecht, br. 1/1995, 25-29.

72 Općinski sud u Zagrebu, Pn-122/99. 
profesije. ${ }^{73}$ Može se uputiti i na presudu kojom je prihvaćena ocjena o terapijskoj pogrešci, jer je nakon operacijskog zahvata malodobni pacijent pao s operacijskog stola i ozlijedio se, što je bilo u uzročno-posljedičnoj vezi s očitim propustom u obavljanju nadzora nad pacijentom u skladu s pravilima struke, etičkim načelima i okolnostima konkretnoga slučaja:

...pošto je tužitelj u doba štetnog događaja bio malodoban te je neposredno pred operaciju bio izrazito uznemiren i uplašen pa se tim više mogla predvidjeti eventualna reakcija tužitelja nakon izvršene operacije (naglo ustajanje s operacijskog stola) te shodno tome izbjeći štetni događaj. Medicinska sestra, iako je upozorila tužitelja da se ne diže soperacijskog stola, propustila je nadzirati tužitelja na način koji je bio nužan te mu je okrenula leđa i nije ga nadgledala cijelo vrijeme nakon operacije niti je s njim komunicirala, a što je bila dužna učiniti, sve do stabiliziranja općeg fizičkog stanja. ${ }^{74}$

\section{ZAKLJUČNE NAPOMENE}

Provedeno istraživanje pokazalo je da se štetna radnja liječnika, kao praesumptio iuris građanskopravne odgovornosti zbog nestandardnoga medicinskog tretmana, može temeljno razlikovati po kriteriju tipologije. Sukladno s tim liječničke pogreške se redovito klasificiraju s obzirom na pojedine stadije dijagnostičko-terapijskog tretmana, te se na temelju kriterija modo et forma mogu podijeliti na dijagnostičke i terapijske liječničke pogreške s korelativnim podoblicima. Per exemplum, kada je u pitanju terapijska liječnička pogreška ona po prirodi medicinskoga protokola obuhvaća i, tzv. komunikacijske liječničke pogreške koje nastaju zbog nepravilne komunikacije između subjekata medicinskoga tretmana. Uz to, praksa poznaje zaseban modus liječničkih pogreški sui generis koje se mogu označiti pojmom nestandardne ili atipične liječničke pogreške, a koje se faktično ozbiljuju kao slučajne povrede u sklopu medicinskoga tretmana prouzročene nedostatnom pozornosti liječnika i/ili medicinskog osoblja.

Provedena komparativna analiza sudske prakse dovela je do zaključka kako se terapijska liječnička pogreška može podijeliti u dvije osnovne grupe. U prvom slučaju do liječničke pogreške dolazi kada se terapijski postupak provodi na način koji nije $u$ skladu s pravilima zdravstvene struke, kao suboptimalni tretman contra legem artis u aktivnom obliku pogreške. U drugom slučaju do liječničke pogreške dolazi zbog stručnih propusta kada posljedično izostaje terapijski postupak koji zahtijeva važeći medicinski standard, u pasivnom obliku pogreške. Provođenje terapijskoga postupka utemeljenog na općem medicinskom standardu uvijek je zahvat intuitu personae te mora uzeti u obzir sve posebne zdravstvene okolnosti na strani pacijenta koje su bitne za postizanje terapijskog cilja, a između ostalih i dob pacijenta, budući da pojedini terapijski zahvati mogu imati različite medicinske implikacije ovisno o pacijentovoj dobi. $^{75}$

73 VSRH, Rev 60/07-2.

74 Županijski sud u Zagrebu, Gžn-1094/06.

75 VSRH, Rev 829/06-2. 
In fine nužno je naglasiti da svako postupanje koje nije u svemu usklađeno s općeprihvaćenim medicinskim standardom neće uvijek biti kvalificirano kao liječnička pogreška, a posebno u situacijama kada takav odmak uvjetuju specifične zdravstvene okolnosti na strani pacijenta $u$ okvirima stručnog personaliziranog tretmana. Naime, od liječnika se očekuje da u svakom slučaju procijeni je li primjena određenoga dijagnostičkog i/ili terapijskog postupka u korelaciji s rizikom koji se razumno može prihvatiti uzimajući u obzir kliničku sliku pacijenta.

\section{LITERATURA}

Knjige i članci:

1. Crnić, Ivica. Odgovornost liječnika za štetu. Zagreb: Organizator, 2009.

2. Ćepulić, Egidio. „Profesionalna odgovornost liječnika i skandinavski model osiguranja liječnika (no fault compensation system)". U: Profesionalna odgovornost liječnika, ur. Tatjana Josipović. Zagreb: Hrvatska liječnička komora, 2007.

3. Deutsch Erwin i Andreas Spickhoff, Medizinrecht, Arztrecht, Arzneimittelrecht, Medizinprodukterecht und Transfusionsrecht, Fünfte, neue bearbeitete und erweiterte Aufl. Berlin: Springer, 2003.

4. Grubb, Andrew i Judith Laing. Principles of medical law. Oxford: Oxford University Press, 2004.

5. Ferrara, Santo Davide, Rafael Boscolo-Berto i Gudio Viel, ur. Malpractice and Medical Liability. Berlin: Springer Science and Business Media, 2013.

6. Franzki, Harald. „Behandlungsfehler“. U: Lexikon Medizin, Ethik ur. Albin Eser, Markus von Lutterotti i Paul Sporken. Freiburg: Herder, 1989.

7. Giesen, Dieter. International Medical Malpractice Law: A Comparative Law Study of Civil Liability Arising from Medical Care. Tübingen - Dordrecht: Mohr, Nijhoff, 1988.

8. Klarić, Petar. „Odgovornost zdravstvene ustanove i zdravstvenih djelatnika za štetu (Prvi dio)“. Hrvatska pravna revija 1, br. 8 (2001): 17-35.

9. Polajnar Pavčnik, Ada. „Zaplet, napaka in pravne posledice“, u: Medicina in pravo: sodobne dileme, ur. Jelka Reberšek Gorišek et al. Maribor: Pravna fakulteta - Splošna bolnišnica, 2006.

10. Radišić, Jakov. Odgovornost zbog štete izazvane lekarskom greškom u lečenju i u obaveštavanju pacijenta. Beograd: Nomos, 2007.

11. Škavić, Josip i Dušan Zečević. „Komplikacija i greška - sudskomedicinski pristup“. U: Građanskopravna odgovornost u medicini: okrugli stol, ur. Jakša Barbić. Zagreb: HAZU, 2008.

12. Tarantino, Umberto et al. „Profesional Liability in Orthopaedics and Traumatology in Italy“. Clinical Orthopaedics and Related Research 471, br. 10 (2013): 3349-3357.

13. Traina, Francesco. „Medical Malpractice: Experience in Italy“. Clinical Orthopaedics and Related Research 467, br. 2 (2008): 434-442.

14. Vojković, Hrvoje. Građanskopravna odgovornost za liječničku pogrešku: doktorska disertacija. Zagreb: Pravni fakultet Sveučilišta u Zagrebu, 2013.

15. WHO Europe, Patient Safety, Data and statistics. Pristup 4. listopada 2019. http://www. euro.who.int/en/health-topics/Health-systems/patient-safety/data-and-statistics

Pravni propisi i sudska praksa:

1. Bovenzi v. Kettering (1991.)

2. Budgen v. Harbour View Hospital (1947.)

3. Collins v. Hertfordshire County Council (1947.)

4. Corder v. Banks (1960.)

5. Greenhorn v. South Glasgow University Hospitals NHS Trust MLC 1556 (2008.) 
6. Hucks v. Cole (1968.)

7. John R. Doherty vs. Debra J. Aleck (2007.)

8. Općinski sud u Slavonskom Brodu, P-1320/98-32 od 16. srpnja 2007.

9. Općinski sud u Zagrebu, Pn- 122/99 od 31. svibnja 2004.

10. Općinski sud u Zagrebu, XXXV-Pn-3831/99 od 20. veljače 2008.

11. Pittman Estate v. Bain (1994.)

12. Pollard v. Chipperfield (1952.)

13. Prendergast v. Sam \& Dee Ltd (1989.)

14. Richardson v. Winchester \& Eastleigh Healthcare NHS Trust MLC 1552 (2008.)

15. Savezni vrhovni sud Njemačke (BGH), presuda od 7. srpnja 1994., Medizinrecht, br. 1/1995, 25-29.

16. Savezni vrhovni sud Njemačke, presuda od 17. prosinca 1991., Medizinrecht, br. 3/1992, 159-161.

17. Savezni vrhovni sud Njemačke, presuda od 26. siječnja 1999., Medizinrecht, br. 7/1999, 321-323.

18. Vrhovni sud Austrije, 6Ob75/08k od 7. srpnja 2008.

19. Vrhovni sud Austrije, 40b75/08w od 10. lipnja 2008.

20. Vrhovni sud Austrije, 90b79/07v od 8. veljače 2008.

21. Vrhovni sud Republike Slovenije, II Ips 524/2004. od 20. listopada 2005.

22. Vrhovni zemaljski sud u Oldenburgu, presuda od 20. prosinca 1994., Medizinrecht, br. 8/1995, 326-328.

23. Vrhovni zemaljski sud u Stuttgartu, presuda od 2. veljače 1989., Versicherungsrecht, br. 18/1989, 632-633.

24. VSRH, Gzz 249/03-2 od 22. siječnja 2003.

25. VSRH, Rev 1022/2015-3 od 16. siječnja 2019.

26. VSRH, Rev 1584/1998-2 od 4. veljače 1999.

27. VSRH, Rev 1902/2013-2 od 30. svibnja 2017.

28. VSRH, Rev 1918/01-2 od 22. studenog 2001.

29. VSRH, Rev 20/2009-2 od 5. siječnja 2012.

30. VSRH, Rev 3010/2014-2 od 3. svibnja 2017.

31. VSRH, Rev 494/2012-2 od 12. travnja 2016.

32. VSRH, Rev 597/06-2 od 6. ožujka 2007.

33. VSRH, Rev 60/07-2 od 9. svibnja 2007.

34. VSRH, Rev 829/06-2 od 6. rujna 2006.

35. VSRH, Rev 876/2006-2 od 10. siječnja 2007.

36. VSRH, Rev x 232/2008-2 od 18. veljače 2009.

37. VSRH, Rev x 848/2017-2 od 31. listopada 2017.

38. Zakon o kvaliteti zdravstvene zaštite, Narodne novine, br. 118/18.

39. Zakon o zaštiti pučanstva od zaraznih bolesti, Narodne novine, br. 79/07., 113/08., 43/09., 130/17., 114/18., 47/20., 134/20.

40. Županijski sud u Bjelovaru, Gž. 995/2016-2 od 28. rujna 2016.

41. Županijski sud u Rijeci, Gž. 2380/2016-4 od 19. prosinca 2018.

42. Županijski sud u Slavonskom Brodu, Gž-294/03-2 od 15. ožujka 2005.

43. Županijski sud u Zagrebu, Gž 5602/2017-2 od 8. svibnja 2018.

44. Županijski sud u Zagrebu, Gžn-1094/06 od 18. travnja 2006. 


\section{Hrvoje Vojković*}

Summary

\section{MODALITIES OF MEDICAL MALPRACTICE WITH REFERENCE TO THERAPEUTIC MEDICAL ERROR IN CROATIAN AND COMPARATIVE PRACTICE}

The research of the manifestations of harmful actions of physicians (medical malpractice) starts from the basic obligation of physicians to apply a generally accepted medical standard when providing health care, as well as a standard of due care that is adequate to the medical profession. The paper investigates the legally relevant modalities of violation of the medical standard and presents a fundamental classification of diagnostic, therapeutic and atypical medical errors with emphasis on the manifestations of therapeutic errors in medical and legal practice in Croatia and ad comparandum. In this sense, an important area of research is the collected representative compilation of domestic and foreign practice in the period within 25 years. The concluding remarks complete the general typology of legally relevant harmful actions that violate the medical treatment of physicians, in accordance with the norms of positive law and the accepted views of court practice.

Keywords: civil liability of physicians; due care of physicians; violation of medical treatment standards, therapeutic medical malpractice.

* Hrvoje Vojković, Ph.D., Gras Savoye Croatia d.d. Zagreb, Willis Towers Watson Group; hvojkovic@gmail.com. ORCID: https://orcid.org/0000-0002-2531-2460. 
